\title{
Typification of names based on the Angolan collections of Friedrich Welwitsch
}

\author{
Sara Albuquerque ${ }^{1}$, R.K. Brummitt ${ }^{1} \&$ Estrela Figueiredo $^{2}$ \\ ${ }^{1}$ The Herbarium, Royal Botanic Gardens, Kew, Richmond, Surrey, U.K. s.albuquerque@kew.org \\ (author for correspondence) \\ ${ }^{2}$ H.G.W.J. Schweickerdt Herbarium, Department of Botany, University of Pretoria, Pretoria, \\ 0002 South Africa
}

\begin{abstract}
The background to Friedrich Welwitsch's seven year expedition to Angola and the subsequent fate of his herbarium of 10,000 collections are reviewed. In typifying the approximately 1,000 species names based on his collections, it is important to know where the specimens were at the time of publication of the names. In most cases there are no holotypes, and lectotypifications have to be made. It has not been generally realised that Welwitsch lumped together under one number all the collections which he considered to be conspecific, which means that designation of isotypes is open to serious misinterpretation. Data added retroactively to labels by copying from Hiern's Catalogue may be erroneous. The collection has now been distributed to at least 24 different herbaria.
\end{abstract}

KEYWORDS: Angola, BM, LISU, typification, Welwitsch collections

\section{INTRODUCTION}

The plant collections discussed here have been widely regarded as one of the most significant ever made in tropical Africa. About 1,000 new species have been described based on these specimens. While much has been written about the life of the collector (Trimen, 1873; Hiern, 1896; Dolezal, 1960, 1961, 1974; Swinscow 1972) about the extant archives in London (Edwards, 1972), and about the famous court case which determined where the specimens should be deposited (Stearn, 1973), surprisingly little attention has been paid to where the material was held at different times, how it was worked on, and how the names based on his collections are to be typified. Indeed, incorrect assumptions are regularly made about the typification of these names. Participation in two current projects, the African Plants Initiative (S.A. and E.F.) and an account of the Rubiaceae of Angola (Figueiredo, 2008), have focussed attention on these problems, and S.A. has been funded to spend time examining archives in London and Lisbon. Below we try to summarise the facts necessary for understanding the problems involved, and to provide a little background information. More detailed historical and archival information will be provided in a separate paper elsewhere.

\section{THE ANGOLAN EXPEDITION}

Friedrich Martin Josef Welwitsch (1806-1872), was born in Austria but moved to Portugal in 1839 where he was variously employed as a botanist. In 1851 the Portuguese government approved a project to send a botanist to Angola, and the king, D. Fernando II, recommended Welwitsch for the position. His objective, as required by the Portuguese government, was to collect plants and animals of Angola for scientific analysis, to ascertain their economic potential, and to develop the riches and wellbeing of the inhabitants. On 8 August 1853, at the age of 47, he departed for Angola, arriving in Luanda on 29 September. He was to spend the next seven years travelling through the present-day provinces of Luanda, Bengo, Cuanza Norte (where he spent two years in Golungo Alto), Malange, Benguela, Namibe and Huíla (Hiern, 1896). He collected both botanical and zoological specimens, and made detailed field notes on their description, distribution, habitat and economic potential. He made probably over 10,000 botanical collections (including cryptogams), representing around 5,000 species.

When Welwitsch was in Angola he communicated by sea-mail with European botanists, and occasionally sent seeds and living plants to different places in Portugal such as Lumiar, Coimbra, Necessidades and S. Miguel (Azores) (Welwitsch, 1854, 1856). He also prepared and organized a collection of natural products from Angola to be forwarded to the Portuguese section of the Paris Exhibition, which took place in 1855 (Hiern, 1896). All the collections he sent from Angola to Portugal were described in the reports to the Portuguese Government, published in the Annaes do Conselho Ultramarino, where his Apontamentos Fito-geográficos appeared in 1858 including short descriptions of 52 new species. 


\section{RETURN TO EUROPE}

After a final long expedition to the south-west of Angola, where he made his discovery of the extraordinary plant now known as Welwitschia on 3 September 1859, he gathered his specimens of plants, insects, molluscs and some mammal skins in Luanda, and set sail for Portugal in December 1860, arriving in Lisbon at the end of January 1861. Later that year, the king, D. Pedro V (son of D. Fernando II) died, which was the start of increasingly difficult dealings with the Portuguese government. Finding he was unable to identify his plants in Portugal, Welwitsch managed to persuade the government that he should move with his collections to London. He arrived in London on 20 October 1863. But in view of the apparently very slow progress made with identifications, the Portuguese government, now ruled by D. Luis I (brother of D. Pedro V) became increasingly impatient with him and reluctant to continue to finance his work.

Welwitsch retained the specimens in the three houses where he lived at different times, all in the area now known as the West End of London. He proceeded to try to name the plants in visits to the nearby British Museum in Bloomsbury (the Natural History Museum at South Kensington only opened in April 1881, Stearn 1981) and at Kew $(\mathrm{K})$ about seven miles to the west. Understandably, he felt very possessive about his collections, but he was also keen to show them to taxonomic specialists in London and from other parts of Europe whenever possible. He seems to have been happier with the co-operation he received at BM, sometimes finding the botanists at Kew, where the early volumes of the Flora of Tropical Africa were being prepared, too much preoccupied with their own work to spend time with him. Sadly, a serious fire in his house threatened the whole collection. Fortunately it was saved, but this caused him great trauma and his health deteriorated. On 20 October 1872, Welwitsch died in London.

\section{THE FATE OF THE HERBARIUM}

Three days before he died, he prepared a will in which he expressed the wish that his collections be deposited in BM and other herbaria. The whole zoological and botanical collection from Angola was taken, in late 1872, from his house to a room entirely devoted to them in the basement of the British Museum (Bloomsbury). However, the Portuguese government demanded the return of the collections to Lisbon. As a consequence, the ownership of the material was subject to a complex legal dispute which put the Portuguese government, represented by J.D. Hooker, Director at Kew, in opposition to the custodians of the collections in London. It was only in November
1875 , after an extended court case, that an agreement was reached between the parties. It was decreed that the main set (called the 'study set') and the original notes and descriptions should be returned to Lisbon (today specimens and notes are housed at LISU Herbarium, Botanic Garden of Lisbon), the second best set and a copy of the written material should remain in London at BM (now the Natural History Museum), and the remaining sets passed to other institutions (Stearn, 1973).

On the recommendation of J.D. Hooker, W.P. Hiern, who had worked at Kew and was friendly with Welwitsch, was employed to divide the collections up. He based his work on the numbers which Welwitsch had assigned to the collections, but the numbering is complex and the separation of different sets was sometimes unsatisfactory as a result. We have no evidence that Welwitsch used a numbering system in the field. It appears that he took notes when he was collecting specimens, but only later did he give numbers to them when he was organizing the material either in Angola or later in London. The numbers he gave are not in chronological order. He sorted the specimens into family sequences, but there are often several sequences in the same family. For example, in Rubiaceae there are at least five different sequences (1115-1120, 1508, 2562-2584, 3027-3252, 4744-4758 and 5304-5355) which bear no relation to the year or province of the collection. We can see no pattern in how or why this was done.

A particularly important point, which is not immediately obvious from Hiern's Catalogue produced later and which has been overlooked by many taxonomists ever since, is that most of the plants which he considered to be the same species were given the same number, even though they were from different localities and with different collection dates (e.g., number 2517, determined as Peucedanum fraxinifolium, was collected at Bango Aquitamba, in Feb. 1855 and at Serra de Alto Queta in Aug. 1855). Welwitsch's attitude to his collection was not merely taxonomic, for he was also making ecological and phytogeographical observations. He therefore tried to summarize on his labels all his information, including data on phenology, for each species he thought distinct. He also wrote Latin descriptions of many species he recognised in the field, apparently basing these on all the specimens that he thought were conspecific. Unfortunately his practice of merging different collections under the same number causes typification problems nowadays.

He did, however, sometimes add the letters b, c or d, apparently either when the localities were widely separated (e.g., Oxyanthus pallidus collected in Pungo Andongo, 2582 and Golungo Alto, 2582b) or if he thought something might be taxonomically distinct (e.g., Franchetella arborescens 2508 and 2508b, both from the same locality but with notes on different characters). In those 
cases where there are different numbers for the same species, it appears that Welwitsch considered that they were different species but, in the Catalogue, Hiern put them together (e.g., Cussonia angolensis, 479, 480 and 481). In rare cases it seems that Welwitsch or Hiern added "bis" after a number to distinguish different collections (e.g., Burkea africana 574bis). Sometimes different numbers were also given to the carpological collection (e.g., Lefebvrea angolensis, where Coll. Carp. 630 cannot be positively associated with any of the four specimen numbers). Some carpological material is available at least in LISU, Kew and probably BM.

After the court case, Hiern started, in late 1875 , working at BM (Bloomsbury) on the task of extracting the set to stay there, continuing until early 1877 when he retired to his estate in Devon. In the work at BM he was assisted by a Mr. Scholvein (sometimes written Scholvien) who transcribed Welwitsch's original handwriting on to the labels of the BM set. Edwards (1972) has drawn attention to the existence of a Catalogus Geographicus in the archives at BM. This consists of a list of Welwitsch numbers in numerical sequence with localities in the left column and with an apparently preliminary identification in the right column. It is in two parts, the first in the very characteristic well-formed handwriting of Scholvein (numbers 1 to 1866). However, Scholvein left the project in October 1877, apparently leaving the work to be continued by Hiern, whose handwriting is found in the second part (numbers 1867 to 3026). This seems to be a forerunner of the eventual catalogue, but the Catalogus Geographicus was never completed.

When Hiern left London in 1877, the separation of the sets was not complete, and he continued to send instructions to W. Carruthers, Keeper of Botany at BM, for Mr. Scholvein's work until October that year. According to Tavares (1959), the first batches of the Angolan collections probably came from London to Lisbon in mid 1876 and the last arrived on 26 October 1879. These included everything except the BM set. The work in Lisbon of separating the sets for other herbaria fell to Count Ficalho who started the process probably in 1877 assisted by António Ricardo da Cunha and E. Goetze, who had earlier worked with J.D. Hooker at Kew (Tavares, 1967). These sets were distributed in batches largely based on groups of families. We know, for example, that the Kew sets were sent from Lisbon in eight batches between April 1877 and March 1883 and included 3,942 specimens. The sets for other herbaria continued to be sent from LISU until the 1970s. Apart from the two top sets at LISU and BM, Welwitsch's Angolan collections are now found in B, BR, C, COI, E, G, K, L, LE, M, MEL, MO, MPU, NU, NY, P, PO, PRE, STU, U, WAG and WU, as recorded in the very recent African Plants Initiative (see www.aluka.org) which has digitized images in most of these herbaria.
During the distribution of the collections, several different kinds of labels were used, with different handwritings. The specimens distributed from LISU had labels headed "Escola Polytechnica", usually with only a species name and Welwitsch's number and occasionally a single word locality. We do not know how many sets he usually collected in the field. In modern literature there may often be perhaps five or six herbaria cited for one number, but because of the problems in Welwitsch's numbering (see above) we cannot be sure that all specimens given the same number were in fact duplicates of one collection. It appears that some of the receiving herbaria added much information to the labels sent by LISU by uncritically copying data from Hiern's Cata$\operatorname{logue}$, and some of the labelling may be misleading. Red labels stating "Typus" have often been added to the LISU specimens, but being unpublished these have no status in determining types and seem to be independent of small type labels at BM.

\section{HIERN'S CATALOGUE}

It was probably at the suggestion of J.D. Hooker that Hiern began to compile the Catalogue of Welwitsch's African Plants in 1875. Swinscow (1972) has stated that he stopped this work in 1877 when he retired to Devon, but this seems not to be correct. Hiern's correspondence with Carruthers shows that he continued his study in Devon, receiving specimens on loan from $\mathrm{BM}$. He is known to have collaborated with Ficalho in 1881 (whether in Lisbon or in correspondence is not clear) and he also made at least one visit of several weeks to Lisbon in 1882. In 1892, he returned to London from Devon to work full time on the Catalogue. Volume 1, consisting of four parts containing 1035 pages, was compiled by Hiern and published between 1896 and 1900, while volume 2 included a first part containing the Monocotyledons by A.B. Rendle and appeared in 1899, and the final part, including Cryptogams by W. Carruthers, was published in 1901.

Hiern's aims for the Catalogue were firstly to give an up-dated nomenclature for all species, and secondly to publish a transcription of all Welwitsch's field notes attached to the specimens, including his descriptions. Hiern used Welwitsch's notes, making the translations of the descriptions from Latin to English, sometimes adding his own observations, in the Catalogue. For species names which had not been previously published, when Welwitsch had written a binomial name accepted by Hiern, this was cited in the catalogue with the author 'Welw. ms. in Herb.'. Because only the name and not the description was ascribed to Welwitsch, the names must be now attributed to a later validating author (often Hiern) - see Art. 46.2 of the ICBN (McNeill \& al., 2006). If Welwitsch had not 
given a binomial, Hiern gave a new name followed by 'Hiern, sp.n.'. The descriptions of these new species are largely based on those written by Welwitsch, sometimes with details added by Hiern.

The Catalogue is of course still useful today, but it unfortunately does not record where the specimens were seen. The type method was only introduced into the rules of nomenclature several decades later. For the parts written by Hiern, it is likely that he was working mostly on the BM set. However, since he was friendly with Hooker and other Kew botanists, and had worked with Oliver on the Flora of Tropical Africa there, it is very likely that he also consulted the Kew set while he was in London. He also visited Lisbon (see above) and some species were described jointly with Ficalho. It is important to note, however, that since Hiern worked through the entire collection, he must have had all the material in his hands at one time or another.

\section{TYPIFICATION OF NAMES BASED ON THE COLLECTIONS}

Typification of the 52 names published by Welwitsch himself in his Apontamentos while still in Angola is problematic. On page 593 of that publication there is a list of plants grown in Portugal from the seeds sent by Welwitsch on 27 November 1858 where there is just reference to the family name, collection numbers and the gardens where they were grown. We are not aware of any specimens preserved of these cultivated plants, but if any such material should exist it should probably be sought in Portugal. For typification of the many names based on Welwitsch's collections after his return to Europe, it is important to assess where the specimens were, and where the author of the names was working when the description was drawn up.

One of the present authors (R.K.B.) remembers that 40 years ago at Kew, for example, there was a general assumption that the holotype should always be the specimen now at LISU, but this is unjustifiable. It depends on which specimens were seen by the author, and bearing in mind the numbering system (see above) this can be difficult to ascertain. From 1863 to his death in 1872 the collections were based in Welwitsch's house, but were made available to botanists wishing to see them. A letter pasted into the Conspectus Florae Angolensis at Kew, written by A. Exell to J.P.M. Brenan on 18 April 1972, says that material was loaned to Kew by Welwitsch in this period. Welwitsch himself published one major taxonomic work, his Sertum Angolense (1869), and the 47 new species described there would have been based on the whole herbarium which may now be distributed to any of the herbaria listed above. All extant specimens must be treated as syntypes. Between 1873 and 1876 the collections were all kept together at the British Museum. From 1876 to 1879 , all material except the BM set was being transferred to Lisbon.

Typification of names first published in the Catalogue has been much misunderstood. Welwitsch's collections at BM have mostly only a label reading 'Type' with the name of the taxon written in pencil at the bottom of the sheet, which does not give any definitive indication of Hiern's intentions in type designations. In accounts written up to 1877 , he may have had all the material of the taxa he described in front of him, so a lectotype could now be chosen from any of the material subsequently widely distributed. This might apply to names in the earlier parts of the Catalogue. But much of the Catalogue was probably written after 1892, when Hiern would have had access only to the BM and Kew sets. On the other hand, we also have to remember that Hiern was very largely basing his descriptions on those written in the field by Welwitsch, which were often compilations based on several different collections. Apart from those published by botanists working at other institutions, it is dangerous to treat any names as having holotypes, particularly bearing in mind Welwitsch's practice of merging different collections under one number. Lectotypifications should be made and bearing in mind the likelihood of mixed collections under the same number a first critical consideration should be whether the specimen matches the published description. Assuming that it agrees, but not compulsory, to choose lectotypes of these names it would then seem preferable, from either BM or Kew, with BM having the greater claim since Hiern must have spent most of his time working there. Hiern also described some of Welwitsch's collections in other publications, such as his revision of Coffea in Africa (Hiern, 1876) and his various contributions to the Flora of Tropical Africa.

Names of species first described by other authors must be viewed differently. In many cases, Welwitsch wrote a new species name on a specimen but never published it. These names were taken up and validated by descriptions by other authors, especially in the Flora of Tropical Africa, and authorship is cited in modern times with an 'ex' citation. The specimen on which Welwitsch himself wrote the name is not necessarily the holotype, since it depends what material the describing author used. To determine this, the history of the collection outlined above must be considered. Names based on specimens which Welwitsch sent to specialists before he died are most likely to be typified by material in the herbarium of the author of the name, which, if it can be shown to be the one specimen used by the author may even be regarded as a holotype. Names published by others after 1872 should similarly most probably be typified by a specimen held where the author was working. 
Above all, it is important to recognise that the numbers attached to the specimens do not necessarily indicate that all with the same number are the same collection (see above). In particular, care should be taken over citing isotypes or isolectotypes based only on the number attached. If the material under one number appears to be from different collections, the specimens should not be cited as isotypes.

\section{SOME EXAMPLES OF RECENT} PROBLEMS

The Conspectus Florae Angolensis (Exell \& Mendonça, 1937, 1951, 1954, 1955; Exell \& Fernandes 1962, 1966; Exell \& al., 1970; Schelpe \& al., 1977; Fernandes, 1982; Diniz, 1993) is a synoptical account of the flora and started in 1937 as a multi-volume project, but is still far from complete. It includes keys but not descriptions, and cites all specimens seen, including those of Welwitsch, citing all the herbaria in which each number has been seen. In the early volumes, covering Ranunculaceae to Leguminosae in the Bentham \& Hooker system, a specimen in one herbarium was indicated as 'tipo', sometimes that at LISU and sometimes at BM, and these should now be treated as lectotypes. Occasionally a specimen at Berlin was cited where a species was described by German authors, and these may be treated as holotypes since it is unlikely that the authors saw more than that. Whether the specimens in other herbaria cited for these numbers should be cited as isotypes is debatable in the light of Welwitsch's numbering. In volume 4, covering Rosaceae to Araliaceae (Exell \& al., 1970), the LISU specimen is usually cited as either holotype or lectotype, but we would prefer to treat these all as lectotypes with all the possible qualifications that entails. Two papers by Romariz (1950-1952) listing types held at LISU seem to merely repeat information from the first three volumes of the Conspectus.

Current work on Rubiaceae (Figueiredo, 2008) has brought to light further problems in recent literature. Robbrecht (1979) cited LISU specimens as holotypes, for example for Tricalysia glabra K. Schum., even though in this case it seems that there was a holotype in B destroyed during the second World War, and the LISU, COI, K and $\mathrm{P}$ specimens are possible isotypes. Bridson (1985) cited two syntypes at LISU and isosyntypes at BM and $\mathrm{K}$ for Canthium welwitschii Hiern, Cat. 1: 475 (1898), but these should all be treated as equal syntypes. Likewise, Verdcourt (1987) considered that the holotype of Canthium platyphyllum Hiern, Cat. 1: 479 (1898) was kept at LISU and the specimen at BM was an isotype. Cheek \& Dawson (2000) lectotypified Coffea hypoglauca Welw. ex Hiern in Trans. Linn. Soc. London, Bot. 1: 173 (1876) selecting (reasonably) a BM specimen, but wrongly explaining that Welwitsch's first set was returned to Lisbon in 1873 before the name was validated by Hiern and 'it is very likely that Hiern working at the BM did not see the LISU specimens'. Where, prior to 2001, a specimen has been wrongly stated in a publication to be a holotype, this is treated as an error for lectotype (Art. 9.8 of the $I C B N$ ). However, the current requirement in Art. 7.11 for the statement "designated here" for a lectotypification to be effective precludes such correction. In none of these cases discussed above is there a suggestion that Welwitsch mixed collections under the same number, but in other cases one should always bear this possibility in mind.

The location of Welwitsch's collections in Lisbon has also been the cause of some confusion. For Ancylanthos cinerascens Hiern, Verdcourt (1987) cited as type Welwitsch 3162 (holo- LISC, iso- BM, K). In fact there are no duplicates of Welwitsch's collections at LISC, although that is now the largest herbarium in Lisbon. This mistake has been found in other instances, and in other families. For example, in the same volume of Kew Bulletin, in the family Proteaceae, the type of Leucadendron micans Hiern is referred to as 'Welwitsch 1589 (lectotype LISC chosen by Beard 1963, isolecto- BM, K)' (Chisumpa \& Brummitt, 1987). Beard (1963) had wrongly referred to the type as 'Welwitsch 1589 (LISC holo-; BM, B, K, G, $\mathrm{P}$ iso-)'.

With the digitisation of type specimens for the African Plants Initiative, it is expected that many typification problems relating to Welwitsch's collections will come to light. Since Angola has not been included in any major Flora and the Conspectus Florae Angolensis is far from complete, many names based on these collections are still not properly typified. As images from different herbaria are gathered and information compared, there will be discrepancies, and the information will have to be reviewed. In the meantime, it is proposed here that authors revising groups and having access to these types should undertake lectotypifications in the light of our comments above.

\section{ACKNOWLEDGEMENTS}

Research by S.A. in archives and herbaria at the Natural History Museum (BM) and the Royal Botanic Gardens-Kew (K) was possible thanks to the funding of Synthesys (European Union-funded Integrated Infrastructure Initiative grant) and the Bentham-Moxon Trust (Kew). Special thanks are due to Steve Cafferty at BM and all those who work at BM and Kew Archives and Libraries. S.A. is also very grateful to Dr. Ana Isabel Correia at the Botanic Garden of Lisbon (LISU). Thanks are also due to the curators of many herbaria listed in the text above who have generously provided information. 


\section{LITERATURE CITED}

Beard, J.S. 1963. The genus Protea in Tropical Africa. Kirkia 3: 138-206.

Bridson, D.M. 1985. The reinstatement of Psydrax (Rubiaceae, subfam. Cinchonoideae tribe Vanguerieae) and a revision of the African species. Kew Bull. 40: 687-725.

Cheek, M. \& Dawson, S. 2000. A synoptic revision of Belonophora (Rubiaceae). Kew Bull. 55: 63-80.

Chisumpa, S.M. \& Brummitt, R.K. 1987. Taxonomic notes on tropical African species of Protea. Kew Bull. 42: 815-853.

Diniz, M.A. 1993. Bignoniaceae. Conspectus Florae Angolensis, Fam. 122. Instituto de Investigação Científica Tropical, Lisbon.

Dolezal, H. 1960, 1961. Friedrich Welwitsch: Leben und Werk. Portugaliae Acta Biol., Sér. B, Sist. 6: 257-323; 7: 49-276.

Dolezal, H. 1974. Friedrich Welwitsch Vida e Obra, traduzido $e$ anotado por A.W. Exell \& E.J. Mendes. Junta de Investigações Científicas do Ultramar, Lisboa.

Edwards, P.I. 1972. Friedrich Welwitsch, 1806-72, his manuscripts and correspondence in the Departments of Botany and Zoology, British Museum (Natural History), the Linnean Society of London, and the Royal Botanic Gardens, Kew. Biol. J. Linn. Soc. 4: 291-303.

Exell, A.W. \& Mendonça, F.A. 1937, 1951, 1954, 1955. Conspectus Florae Angolensis, vol. 1, fasc. 1; vol. 1, fasc. 2; vol. 2, fasc. 1; vol. 2, fasc. 2. Junta de Investigações Coloniais, Lisbon.

Exell, A.W. \& Fernandes, A. 1962, 1966. Conspectus Florae Angolensis, vol. 3, fasc. 1; vol.3, fasc. 2. Junta de Investigações do Ultramar, Lisbon.

Exell, A.W., Fernandes, A. \& Mendes, E.J. 1970. Conspectus Florae Angolensis, vol. 4. Junta de Investigações do U1tramar and Instituto de Investigação Científica de Angola, Lisbon.

Fernandes, R. 1982. Crassulaceae. Conspectus Florae Angolensis, Fam. 70. Instituto de Investigação Científica Tropical/Junta de Investigações do Ultramar, Lisbon.

Figueiredo, E. 2008. The Rubiaceae of Angola. Bot. J. Linn. Soc. 156: 537-638.

Hiern, W.P. 1876. On the African species of the genus Coffea. Trans. Linn. Soc. London, Bot. 1: 169-76.

Hiern, W.P. 1896-1901. Catalogue of the African Plants Collected by Dr Friedrich Welwitsch in 1853-1861, 5 parts in 2 vols. British Museum (Natural History), London.

McNeill, J., Barrie, F.R., Burdet, H.M., Demoulin, V., Hawksworth, D.L., Marhold, K., Nicolson, D.H., Prado,
J., Silva, P.C., Skog, J.E., Wiersema, J.H. \& Turland, N.J. (eds.). 2006. International Code of Botanical Nomenclature (Vienna Code) Adopted by the Seventeenth International Botanical Congress Vienna, Austria, July 2005. Regnum Vegetabile 146. Gantner, Ruggell.

Robbrecht, E. 1979. The African genus Tricalysia A. Rich. (Rubiaceae-Coffeeae) 1. A revision of the species of subgenus Empogona. Bull. Jard. Bot. Natl. Belg. 49: 239-360.

Romariz, C. 1950-1952. «Tipos» existentes no LISU. Portugaliae Acta Biol., Sér. B, Sist. 3: 238-251, 264-293.

Schelpe, E.A.C.L.E., Jermy, A.C. \& Launert, E. 1977. Conspectus Florae Angolensis, vol. Pteridophyta. Junta de Investigações Científicas do Ultramar, Lisbon.

Stearn, W.T. 1973. The catalogue of the African plants collected by Dr Friedrich Welwitsch (1853-1861) and his litigious background. Garcia de Orta, Sér. Bot. 1: 101-104.

Stearn, W.T. 1981. The Natural History Museum at South Kensington. Heinemann, London.

Swinscow, T.D.V. 1972. Friedrich Welwitsch, 1806-72, a centennial memoir. Biol. J. Linn. Soc. 4: 269-289.

Tavares, C.N. 1959. Acerca de uma carta inédita do Dr. F. Welwitsch. Portugaliae Acta Biol., Sér. B, Sist. 6: 335-342.

Tavares, C.N. 1967. Jardim Botânico da Faculdade de Ciências de Lisboa-Guia. Imprensa Portuguesa, Lisboa.

Trimen, H. 1873. Friedrich Welwitsch. J. Bot. 11: 1-11.

Verdcourt, B. 1987. Notes on African Rubiaceae-Vanguerieae. Kew Bull. 42: 123-199.

Welwitsch, F. 1854. Semina Plantarum. Ann. Cons. Ultramarino, Parte não off. (Apont.), Sér. I: 79-84.

Welwitsch, F. 1856. Relação das plantas vivas, etc., da Flora Angolense que foram remetidas de Luanda, em 21 de Agosto de 1854, ao Conselho Ultramarino, pelo Dr. Welwitsch, com destino a serem enviadas ao Jardim Botânico de Coimbra, e a outros estabelecimentos hortículas de Lisboa. Ann. Cons. Ultramarino, Parte não off. (Apont.), Sér. I: 251-253.

Welwitsch, F. 1858. Apontamentos Fito-Geográficos sobre a Flora da Província de Angola na África Equinocial, servindo de relatório preliminar àcerca da Exploração Botânica da mesma Província Executada por Ordem de Sua Majestade Fidelíssima pelo Dr. Welwitsch. Ann. Con. Ultramarino, Parte não off. (Apont.), Sér. I: 527-580.

Welwitsch, F. 1869. Sertum Angolense, sive stirpium quarundam novarum vel minus cognitarum in itinere per Angolam et Benguellam observatarum description iconibus illustrata. Trans. Linn. Soc. London 27: 1-94. 